\title{
Nutritionally sensitive agriculture-an approach to reducing hidden hunger
}

\author{
Mahtab S. Bamji ${ }^{1}{ }^{1}$ - P. V. V. S. Murty ${ }^{1} \cdot$ Parimala Diana Sudhir $^{2}$
}

Received: 21 August 2020 / Revised: 2 September 2020 / Accepted: 11 September 2020 / Published online: 1 October 2020

(c) Springer Nature Limited 2020

\begin{abstract}
Cereal-based diets of the people in developing countries are qualitatively deficient in micronutrients—vitamins and minerals—due to low intake of vegetables, fruits, legumes and foods of animal origin. Consumption of nutritious millets has also come down in India. Calorie sufficiency may ensure protein sufficiency (though not protein quality), but it does not ensure adequacy of micronutrients. Studies in several countries in Asia, and India show that with education and advocacy even farmers with small and marginal land holdings can be persuaded to raise homestead vegetables and fruits gardens and increase household vegetables consumption. Backyard poultry also has good acceptance and impact on household egg consumption. For best results, the community, especially the mothers have to be educated about the importance of nutrition for health and wellbeing. Studies done by the authors in the villages of Medak district, of the South Indian state of Telangana, show remarkable improvement in the knowledge of food, nutrition, hygiene and health of mothers with children under 3 years of age, with education-behavioural change communication. Impact of nutrition gardens and backyard poultry with high egg-yielding breeds had positive impact on the household consumption of vegetables and eggs.
\end{abstract}

\section{Introduction}

Developing countries like India are facing a double burden of diseases. While pre-transition diseases like infectious diseases and malnutrition persist, there is growing incidence of post-transition non-communicable diseases like obesity, hypertension, diabetes, cardiovascular diseases and cancer. India has become the diabetes capital of the world. Nutrition influences both the burdens. Malnutrition increases susceptibility to infections and resultant morbidity and mortality. Prenatal malnutrition has been shown to affect the growth of the foetus resulting in low birth weight (LBW) babies. Intra-uterine malnutrition epigenetically alters body composition with higher fat deposition, which in turn predisposes the individual to adult-onset non-communicable diseases. (Barker's hypothesis, foetal origins of adult

Mahtab S. Bamji

msbamji@gmail.com

Dangoria Charitable Trust (DCT), Hyderabad 500020, India

2 Department of statistics, Aurora's Degree \& PG College, Hyderabad 500020, India diseases) [1]. WHO has recognised diet as one of the important determinants of health.

The 2019 EAT-Lancet Commission report has compared the food consumption patterns in India, from different income groups, regions and sectors (rural/urban), with the EAT-Lancet reference diet and highlighted the deviations [2]. National Sample Survey Office 2011-2012 data were used for comparison since this is the most recent countrywide data. Except for the richest 5\%, of Indians, the average daily intake of calorie of Indians was below the recommended $2503 \mathrm{kcal} / \mathrm{capita} / \mathrm{day}$. The consumption of fruits, vegetables legumes, meat, fish and eggs were significantly lower. The share of calories from protein sources was only $6-8 \%$, compared to $29 \%$ in reference diet. Though the deficits were higher in the lowest decile of consumption expenditure, even the rich Indian households do not consume adequate quantities of vegetables, fruits and noncereal protein foods. These findings are akin to those of the National Nutrition Monitoring Bureau surveys in India, which show that the cereal-based Indian diets are deficient in the consumption of micronutrient-rich foods like vegetables, fruits, legumes and animal products [3]. Thanks to schemes such as subsidised sale of rice and wheat to families below the poverty line (BPL), through the public distribution system, the consumption of traditional millets 
has also come down. Millets are rich in fibre, many Bcomplex vitamins and minerals. The predominantly cerealbased diets have resulted in rampant qualitative deficiency of micronutrients particularly, vitamins A, B2, B6, B12, folic acid, $\mathrm{C}$ and minerals like iron, zinc and calcium. While calorie adequacy may ensure protein adequacy (though not protein quality), it most often fails to quench the hidden hunger. A recent study from the National Institute of Nutrition, Hyderabad, India, shows a high prevalence of vitamin deficiencies, particularly, vitamins A, B2, B6, B12, folic acid and vitamin $\mathrm{D}$, assessed by subclinical status (blood values) and dietary intakes, in an apparently healthy urban adult population [4]. The overall prevalence of anaemia was $21 \%$. Vitamin deficiencies as judged by blood levels were: vitamin A 6\% (despite much higher dietary deficiency), D 29\%; B1 11\%; B2 50\%; B6 46\%; folate 32\% and active B12 46\%. Vitamin D deficiency has become a major problem even in tropical countries. The dietary intake of all the vitamins except vitamins B1 and B6 were close to or lower than $20 \%$ of Indian reference. That of vitamin B12 was only $4 \%$ and folate $6 \%$. Vitamin $\mathrm{C}$ was not examined. The study population had high incidence of overweight and obesity, and high levels of homocysteine - an independent risk factor for cardiovascular diseases for whose metabolism $\mathrm{B}$ vitamins like folic acid and B12 are required. This shows that even the apparently well-fed Indians from middleincome group suffer from vitamin deficiencies. Mineral status was not examined.

\section{Strategies for combating hidden hunger}

The three basic strategies for combating micronutrient deficiencies are: (i) supplementation with micronutrients (the pharmacy-based approach), (ii) food fortification and (iii) dietary diversification-a farm-based approach [5]. Crop biofortification through conventional breeding, marker-assisted molecular breeding, or genetic engineering, is the technological approach to enrich the germ plasm with specific micronutrients [6,7].

\section{Micronutrient supplementation}

This strategy is generally used to combat severe deficiency of one or two nutrients. India has two micronutrient supplementation programmes [8].

(1) National nutrition anaemia prophylaxis programme. In this programme, all pregnant and lactating women receive $60 \mathrm{mg}$ of elemental iron and $500 \mu \mathrm{g}$ of folic acid (IFA tablets daily) for at least 100 days during pregnancy and 100 days in post-partum period. Preschool children receive $20 \mathrm{mg}$ of elemental iron plus $100 \mu \mathrm{g}$ of folic acid daily. Due to administrative infirmities and lack of awareness regarding the importance of the programme desired results have not been obtained. Education of the community to ensure compliance is very necessary for such programmes to succeed. In 2013, the Ministry of Health and family Welfare, India, launched the National Iron Plus Initiative (2013).

(2) Massive dose vitamin A supplementation programme to prevent nutrition blindness. In this programme, first dose of $100,000 \mathrm{IU}$ of vitamin A is given to children at 9 months of age along with measles vaccine. This is followed by biannual dose of 200,000 IU to children between the ages of 18 and 59 months.

Blindness due to vitamin A deficiency has become rare all over the world, but subclinical vitamin A deficiency (serum vitamin $A<20 \mu \mathrm{g} / \mathrm{dL}$ ) due to dietary deficiency persists. Opinion among nutrition scientists in India is divided about the need for the vitamin A supplementation programme. Its continuation is however needed at least in areas where signs and symptoms of vitamin A deficiency like night blindness and Bitot spots persist. The ultimate effort should be to increase the dietary intake of vitamin A and its plant precursor $\beta$ carotene.

\section{Food fortification}

Food fortification is done either to restore nutrients lost during processing or to enrich foods with nutrients. Food fortification has been defined as 'addition of one or more essential nutrients to a food, whether or not it is normally contained in the food, for the purpose of preventing or correcting a demonstrated deficiency of one or more nutrients in the population or specific population groups' $[9,10]$. It is a convenient and relatively less expensive strategy with a wide outreach and has been used for nutrients like vitamins A, D and some B-complex vitamins and minerals like iron and zinc. The vehicle to be used for fortification should be a food that is consumed by large segments of population regardless of economic status including poorest of poor, and the bioavailability and stability of the fortified nutrients should be good.

One of the successful programmes in India is salt fortified with iodine, which has now become a universal programme. The National Institute of Nutrition, Hyderabad, India, has developed salt double fortified with iodine and iron. Its use at present is limited. Fat soluble vitamins are often added to oils. Wheat flour is often fortified with minerals and B-complex vitamins, and WHO/FAO has provided guidelines for it [6]. Fortifying oil with vitamins A and D is mandatory in many countries, including India. 


\section{Dietary diversification-a farm-based approach}

The subject of food-based approach including nutrition sensitive agriculture for better nutrition outcomes has been recently reviewed [5, 11-13].

This review discusses some of the studies in India and other Asian countries on nutritionally sensitive farming to combat micronutrient deficiencies.

Thanks to the Green revolution, India has become selfsufficient in the production of cereals like wheat and rice [14]. Production of millets and pulses has however missed the green revolution, but in recent years this shortcoming is being corrected. India ranks among the top two countries in the world for production of milk (white revolution) and vegetables and fruits (rainbow revolution). Even the egg production has gone up markedly. Despite this, the dietary intake of these income-elastic foods remains low in all segments of population, particularly among the poor, due to lack of awareness regarding nutritional importance of these foods and high cost. Even the farmer who produces them prefers to sell them rather than consume at home, because for resource poor farmers with small or marginal land holdings, income is more important than health and nutrition security. Importance of income cannot be denied. Behavioural change communication (BCC) is needed to stress the importance of dietary diversification to ensure food and nutrition security.

High post-harvest losses add to the problem in developing countries, where facilities for cold storage, and processing are inadequate [14]. Agriculture is generally viewed as a source for income and export—at best to meet calorie and protein requirement. The problem of micronutrient deficiencies (hidden hunger) is not understood. Unfortunately, the subject of human nutrition is not in the syllabus of agriculture universities, and hence agriculture extension workers fail to understand the need for leveraging agriculture for nutrition security. The subject of nutrition is also very weakly covered if at all in medical syllabus.

\section{Homestead gardens to combat vitamin A deficiency}

One of the earliest studies on homestead vegetables and fruits gardening (term, used to indicate gardens next to the home or in farms) for micronutrient security was aimed at improving the intake of provitamin A, $\beta$ carotene. It was conducted by the National Institute of Nutrition, Hyderabad, India, in the villages of Andhra Pradesh, India, and the All India Institute of Hygiene and Public Health, Calcutta, West Bengal, India [15, 16]. Seeds and saplings of vegetables rich in $\beta$ carotene (green leafy vegetables (GLV), orange and yellow vegetables and fruits) were given to farmers and farmers advised to grow them near their home or in their farms. Apart from technical knowhow about growing the plants, food and nutrition education was given. In both the centres there was marked increase in the number of families growing $\beta$ carotene-rich vegetables and fruits, their consumption and improvement in understanding of the problem of vitamin A deficiency, foods rich in vitamin A and signs (Bitot spots, xerophthalmia) and symptoms (night blindness) of vitamin A deficiency. Calcutta centre reported reduction in the prevalence of Bitot spots but in Hyderabad centre the results were equivocal. There was some reduction in the common belief that pregnant women should avoid eating papaya since it causes abortion.

\section{Homestead gardens to combat multiple micronutrient deficiencies}

Hellen Keller International has supported an extensive programme of improved homestead gardens and backyard poultry in Bangladesh, Cambodia, Nepal and Philippines to increase the production and household availability of micronutrient-dense vegetables and fruits and eggs. Nutrition education formed an important part of the strategy [17-20]. A significant increase in consumption of vegetables and eggs by mothers and children was recorded, mothers' knowledge of nutrition also improved. Bangladesh and Philippines observed reduction in the prevalence of anaemia. Similar reduction was not seen in Cambodia and Nepal. Families' income also showed some increase through sale of farm produce.

MS Swaminathan Foundation in Chennai, India, is currently exploring the Food system for Nutrition model in few villages of Wardha district of Vidarbha region of Maharashtra, and Koraput district of Odisha, India [21-23]. Community nutrition gardens were also tested. The components of the model are: (1) survey to identify the major nutritional problems, (2) design context-specific suitable agricultural interventions to address the local nutritional problems, (3) improve small farm productivity and profitability, (4) undertake nutrition awareness programmes and build a cadre of hunger fighters and (5) introduce monitoring systems for assessing impact on nutrition outcomes. Location specific vegetables and fruits that are rich in $\mathrm{MN}$ are introduced in homestead gardens. Professor M. S. Swamiathan advocates genetic gardens for nutrition security [22]. Recent evaluation of the impact of this strategy on household food consumption showed remarkable increase in the monthly consumption of fruits and vegetables-frequency as well as quantity, as seen from a baseline survey in 2014 and end-line survey in 2017 of a sample of 190 households in each location [23]. Though the authors mention, health and nutrition education as part of the intervention, no data on its impact are given in the sited paper. 
Urban gardens for food and nutrition related outcomes are yet another promising strategy. It was recently reviewed in $[24,25]$.

\section{Medak studies-authors' experience of homestead gardens and backyard poultry}

\section{Homestead gardens}

For nutrition security there has to be awareness and access at affordable cost to balanced diet and correct feeding practices (food security,) safe drinking water, disease-free environment and health care outreach. This will ensure absorption also. Over the past two decades, the authors (MSB and PVVSM) have tried to develop strategies for each of these in select villages of Medak district in the South Indian state of Telangana (formerly part of Andhra Pradesh). (See www.dangoriatrust.org.in.) This narrative will be confined to the experience with homestead gardens and backyard poultry to enrich the household diet with micronutrient-rich foods.

\section{Study area}

Three studies have been conducted in different sets of villages of Medak district in the South Indian state of Telangana (formerly Andhra Pradesh). The population of the selected villages ranged between 1000 and 3000. Most households had small or marginal landholding, own or leased. Water source for farming was ground water-bore wells or rain-fed. Though water stressed, paddy and sugarcane were the main crops. In dry season, maize or sorghum were grown. Maize was sometimes intercropped with red gram (Cajuns cajan). Only few families raised vegetables. All the households were BPL and eligible for the Indian government's subsidy schemes including subsidised food grains through public distribution system.

Most families belonged to the Hindu backward class category. There were a few Muslim households. Some villages had tribal settlements called tandas attached to them. All households had proper houses, and access to bore well water. In the past few years, government has sponsored two-pit household latrine construction. So now most households have a latrine and claim to use it when asked.

\section{Methodology}

Technological intervention was combined with robust, food, nutrition, sanitation and health education to bring about behavioural change [26-28]. In the first study, March-April 2007 to March-April 2010 [26], 15 villages from four mandals (geographical area) were included.
All families interested to raise vegetable and fruit gardens were invited to join. In the subsequent two studies (March-April 2007-2010, and September 2014 to April-May 2018) covering eight to ten villages (population about 12,000-15,000); families with pregnant women and preschool children were specifically targeted. However, a family approach was used, and husbands often came for training in farming and poultry technologies ([26, 27] and Proceedings of IVth Agricultural Science Congress, New Delhi, India-under publication).

Seeds of a variety of GLV (Amaranth-Amaranthus gangeticus; ambat chuka-Rumex vesicarius; corrrianderCoriandrum sativum; fenugreek-Trigonella foenum-graecum; 'gogu'-Hibiscus, cannabinus; spinach-Spinacia oleracea), and other vegetables like broad beans-Vicia faba; cluster beans_Cyamopsis tetragonoloba; French beans-Phaseolus vulgaris; tomatoes-Lycopersicon esculentum; ladies finger (okhra)_Abelmoschus esculentus and saplings of curry leaves-Murraya koenigii; drumstickMoringa oleifera and Malabar spinach (bachali)_Basella alba were distributed to the target households. GLV are very rich in all micronutrients, are easy to grow and need relatively less water. Some variety or other can be grown throughout the year. Beans are rich in proteins, besides micronutrients. They can fix nitrogen and enrich the soil with nitrogen.

Fruit plants like guava-Psidium cattleyanum; mangoMagnifera indica; papaya-Carica papaya and limeCitrus aurantifolia were selectively given to families who had assured source of water and performed well. Papaya and mangoes are rich in $\beta$ carotene (provitamin $\mathrm{A}$ ) and vitamin $\mathrm{C}$ and guava in vitamin $\mathrm{C}$. Farmers grew vegetables like brinjal (eggplant) and gourds out of choice. Few households had one or two trees of plants like papaya, mangoes, guava, drumstick (Moringa) and curry leaves prior to intervention.

Interested women were taught to raise saplings of plants like papaya, drumstick and bachali (Basella alba, a creeper). The saplings were purchased from them for distribution. Each woman raised 50-100 saplings, and earned some money.

Organic methods of farming like vermicomposting and botanical pesticides-decoction of chilli-garlic paste or neem seed, were also taught to reduce the use of chemical fertilisers and pesticides, mostly the latter.

Centralised meeting (at the DCT campus) and decentralised meetings (hands-on training in the villages) were given. Help from subject specialists in agriculture/horticulture was taken as resource persons for conducting the training programmes. Cooking demonstrations to teach simple foods for complementary feeding were held by involving the mothers. Since the literacy levels in mothers have gone up markedly in recent years, pamphlets with 
Table 1 Impact on cropping pattern based on KAP of mothers with 6-24-month-old children.

\begin{tabular}{lll}
\hline Crop & $\begin{array}{l}\text { Initial } \\
\text { September 2014 } \\
\text { No. 125 (25 } \\
\text { landless) }\end{array}$ & $\begin{array}{l}\text { Final } \\
\text { April-May 2018 } \\
\text { No. 150 }\end{array}$ \\
\hline Rice & 94.4 & 81.3 \\
Maize & 31 & 79 \\
Millets & 2 & 51 \\
Green leafy & 19 & 97 \\
vegetables (GLV) & & \\
Other vegetables & 34.4 & 97 \\
Vermicompost beds & 1.3 & 38 \\
Use of botanical & 0 & 19 \\
pesticides & & \\
\hline
\end{tabular}

Third study. Percentage of households growing.

important messages in the local language Telugu were distributed. Even if the woman was illiterate, there was someone in the family who could read and explain.

\section{Impact assessment}

Impact on acceptance of homestead gardens was done by keeping records of land diverted from traditional crops like paddy and sugarcane to vegetables and fruits, approximate quantum and variety grown and utilised-household consumption vs sale. Families were specifically explained that the purpose of the project was household consumption of home-grown vegetables, particularly by women and children and not for sale. Families were also encouraged to grow pulses and millets.

Improvement in understanding of food, nutrition, sanitation, child caring practices and health (some common infectious diseases - their cause and management) was assessed through initial and end-line knowledge, attitude and practice (KAP) surveys of mothers with 6-24-monthold children using pretested questionnaires. Initial survey was done by the project staff and final survey by a local woman with proper training, to avoid investigator bias.

Household consumption of different foods (weekly frequency, and per capita per day consumption) was assessed by questioning the mothers about food consumed in a typical week when there were no guests and no feasting or fasting [26].

In India, the Integrated Child Development Scheme (ICDS) facilitates preschool education, infant and child feeding and maintenance of records of birth weight and growth of preschool children. All villages above a population of 1000 have one or more ICDS centres called anganwadis, managed by a trained anganwadi workers. In the last two studies, birth weight and monthly growth records of children under 2 years of age were examined to assess the impact on nutrition.

\section{Important observations}

\section{Acceptance of homestead gardens}

Initially less than $30 \%$ of the targeted households grew vegetables or fruits. At the end of the study, $90 \%$ of the households had diverted small bits of land (less than half acre) to growing of vegetables and fruits, despite small and marginal holdings. Table 1 gives data on crops grown, in the last quoted study as reported by the mothers in the KAP survey. A marked increase in the number of households growing vegetables, pulses, maize and millets and a small reduction in households growing rice was reported. Some of these changes in cropping patter may be seasonal effects since the initial survey was done in the month of September and final survey in summer-April-May.

\section{Improvement in mothers' understanding of food, nutrition and health issues}

Comparison of initial and end-line KAP surveys showed remarkable improvement in mothers' knowledge (and hopefully practice) of balanced diet, nutrients in foods, causes and signs and symptoms of nutritional deficiencies, food taboos during pregnancy (avoid foods like papaya and banana), infant feeding practice (initiation of breast feeding, and feeding colostrum, age of introduction of complementary feeding), washing hands with soap and water (not just water), right cooking practices (washing vegetables before cutting, not discarding excess water after cooking rice-a common practice) and causes of common infectious diseases like diarrhoea, malaria, tuberculosis, jaundice and their management $([26,27]$ and Proceedings of IVth Agricultural Science Congress, New Delhi, India-under publication).

\section{Household consumption of vegetables}

In the first two studies, there was significant increase in the frequency $[26,27]$ as well as daily per capita consumption [26] of GLV. Similar significant improvement in the consumption of other vegetables was not seen. The homegrown vegetables replaced what was purchased from the market. However, in the first study where control nonintervention households from the same village were included for comparison [26], there was a marked decline in the consumption of vegetables in the control households over time due to sharp increase in market price of vegetables. This suggests that homestead production at least shields against escalating market price. Monthly inquiries showed 
Table 2 Household food consumption-weekly frequency and quantity consumed per capita per day in the third project.

\begin{tabular}{|c|c|c|c|c|}
\hline \multicolumn{5}{|l|}{ Present study } \\
\hline \multicolumn{5}{|c|}{ KAP survey: September 2014-April/May 2018} \\
\hline \multirow[t]{2}{*}{ Food } & \multicolumn{2}{|c|}{ Initial $N=150$} & \multicolumn{2}{|c|}{ Final $N=150$} \\
\hline & Mean & $\mathrm{SD} \pm$ & Mean & $\mathrm{SD} \pm$ \\
\hline Rice frequency & 7 & \pm 0.000 & 7 & \pm 0.000 \\
\hline g/capita/day & 363.17 & \pm 112.963 & 319.53 & $\pm 351.48^{*}$ \\
\hline Wheat frequency & 0.44 & \pm 1.120 & 0.47 & \pm 0.563 \\
\hline g/capita/day & 6.96 & \pm 17.619 & 10.72 & $\pm 14.095 *$ \\
\hline $\begin{array}{l}\text { Maize/Jowar roti } \\
\text { frequency }\end{array}$ & 1.44 & \pm 2.143 & 1.60 & \pm 2.207 \\
\hline g/capita/day & 21.48 & \pm 44.785 & 32.71 & $\pm 47.694 *$ \\
\hline Vegetables frequency & 2.95 & \pm 1.143 & 3.78 & $\pm 0.499 *$ \\
\hline g/capita/day & 50.364 & \pm 29.941 & 134.87 & $\pm 4576.861 *$ \\
\hline GLV frequency-mean & 1.63 & \pm 0.659 & 2.18 & $\pm 0.464 *$ \\
\hline g/capita/day & 27.535 & \pm 16.105 & 74.52 & $\pm 22.336^{*}$ \\
\hline Pulses frequency & 2.18 & \pm 0.724 & 1.96 & \pm 0.214 \\
\hline g/capita/day & 17.195 & \pm 21.809 & 17.47 & \pm 13.128 \\
\hline Milk: frequency & 6.09 & \pm 2.34 & 6.91 & $\pm 0.75^{*}$ \\
\hline g/capita/day & 71.654 & \pm 52.194 & 120.57 & $\pm 44.84 *$ \\
\hline Eggs: frequency & 1.24 & \pm 0.530 & 1.11 & \pm 0.550 \\
\hline Number/capita/day & 0.18 & \pm 0.103 & 0.17 & \pm 0.165 \\
\hline Meat: frequency & 1.01 & \pm 0.258 & 1.00 & \pm 0.081 \\
\hline g/capita/day & 21.63 & \pm 8.677 & 26.78 & $\pm 3.306^{*}$ \\
\hline
\end{tabular}

Reproduced from the Proceedings of IVth Agricultural Science Congress (under publication), with permission.

${ }^{*} p<0.001$ using Wilcoxon-Mann-Whitney $U$ test.

that about $25-50 \%$ of home-grown vegetables other than GLV were sold in the first study. 'For poor households, economic compulsions outweigh nutritional wisdom' [26]. This trend decreased in the subsequent studies by reiterating the purpose of the study. In the last mentioned study, remarkable improvement in the consumption of GLV as well as other vegetables was observed (Proceedings of IVth Agricultural Science Congress, New Delhi, India-under publication) (Table 2). Very little was sold. The results of that study suggest that with sufficient advocacy, education and training, daily requirement of vegetables, particularly GLV can be met from homestead gardens despite small and marginal holdings. Some incentive like free distribution of seeds and saplings would help. This, however, will not ensure micronutrient security, unless the intake of pulses and animal products also goes up. In that study, some increase in milk consumption was also observed. This may be due to the government scheme of distributing buffaloes at highly subsidised rate.

\section{Impact on child nutrition}

Impact on birth weight and growth of children aged 6-24 months was assessed through the records maintained by the ICDS centres. In recent years, almost all deliveries are institutional. The AW worker maintains records of birth weight and monthly growth. Scrutiny of these records over the study period was done in the second and third studies ([27], under publication). No effect on mean birth weight was observed. The incidence of LBW was less than $10 \%$ compared to the national average of about $20 \%$. The incidence of moderate and severe malnutrition (weight/age) showed marked decline from over $30 \%$ to about $20 \%$. In both the studies, seasonal variation was seen with increase in undernutrition percentage during monsoon. This is a known phenomenon due to greater morbidity during monsoons.

\section{Promotion of backyard poultry with high egg- yielding birds}

Egg is one of the most wholesome foods. Over the years the consumption of meat has come down in India, but that of eggs has gone up due to marked increase in commercial poultry farms $[29,30]$. Commercial farms have largely benefitted urban areas. Backyard poultry is an important option for rural areas, and widely adopted, with nondescript birds with low egg yields-30-40 eggs per year. These birds are well acclimatised, have prominent brooding behaviour and mothering ability. In recent years, improved breeds of BYP, which can lay 150-200 eggs per year, have been developed [28]. Unlike seeds and saplings, which were given free, poultry birds were sold after immunisation. Families bought three birds and one was given free as incentive. Proper night shelters had to be built to prevent predation. Initially two improved breeds Gramapriya developed by the Project directorate, ICAR, Hyderabad, and Rajasri developed by AICP on poultry breeding, Sri Venakteshwara Veterinary University, Hyderabad, were introduced. More recently, older birds of Rainbow rooster breed, purchased from Indbro Research and Breeding Farm, Hyderabad, are being distributed.

In all the projects, the frequency per week of egg consumption by the families initially was less than 2 . Per capita per week consumption was also less than 2 eggs. Subsequent to the introduction of the BYP with high eggyielding birds there was significant improvement. Thus in the two projects, the weekly frequency of egg consumption increased by $73 \%$ and $139 \%$, respectively. Per capita number of eggs consumed per week increased by $347 \%$ and $143 \%$, respectively, [26-28]. 


\section{Rural hub for food and nutrition security}

To facilitate wider dissemination of the model of nutritionally sensitive and environmentally sustainable farming, and backyard poultry (with high egg-yielding birds), along with BCC in the area of, food, nutrition, sanitation and health developed in the earlier projects, DCT has set up a rural hub.

This project was initiated in September 2018, with financial support from Tata, Lock Heed Martin Aero Structures Ltd., Hyderabad, under their corporate social responsibility - CSR for a period of 1 year. It was further continued with financial support of Dangoria Charitable Trust. The design is to target five villages with a total population of eight to ten thousand, over a period of 6 months.

After a month of planning and initial KAP survey of mothers with children under 3 years of age, on aspects of food, nutrition, sanitation and health (as described earlier), four centralised training programmes on topics such as maternal and child health and nutrition; nutrition gardens; backyard poultry and food processing are conducted each month for 4 months. Decentralised hands on training are also given. An end-line KAP survey is conducted in the sixth month. Like in the earlier projects, pregnant women and mothers with children under 3 years of age are the main target. For sustainability the anganwadi workers and accredited social health activists from the villages are involved in the training. Planting material for raising gardens is given free to families with a pregnant woman and children under 3 years. High egg-yielding poultry are given to all interested families. Families buy at least four to five birds.

Hitherto two sets of five villages have been covered. Impact is assessed from the number of families that have started growing vegetables, acceptance of BYP and improvement in mothers' knowledge of food, nutrition, child feeding practices, health etc. as judged from initial and end-line KAP, surveys as described in the earlier longer duration studies. All the families (except three families in the initial survey) had own land. The three families also had leased land. But the holdings were marginal-3-5 acres. Farming and farm labour (working on each other's' farms) was the main occupation. All the women were literate and $80 \%$ had studied beyond fifth standard. Some women had studied up to intermediate.

Results in Table 3 (second set of five villages) show significant increase in the percentage of households growing vegetables at the end of 6 months. Some increase in the number of households having BYP was also seen. There was remarkable improvement in the mothers' knowledge of food consumption during pregnancy, reduction in pregnancy associated food taboos, infant and child feeding
Table 3 Responses of the mothers with 6-24-month-old children, in the KAP survey (rural hub for food and nutrition security).

\begin{tabular}{|c|c|c|}
\hline Question & Initial—\% & End line- $\%$ \\
\hline Growing vegetables and fruits & 28 & $86 * * *$ \\
\hline Growing pulses & 68 & 68 \\
\hline Growing millets & 88 & 82 \\
\hline Having BYP & 10 & 24 \\
\hline \multicolumn{3}{|l|}{ Food consumed during pregnancy and food taboos } \\
\hline More food during pregnancy & 40 & $100 * * *$ \\
\hline $\begin{array}{l}\text { Papaya avoided during pregnancy through fear } \\
\text { of abortion }\end{array}$ & 100 & $10 * * *$ \\
\hline $\begin{array}{l}\text { Banana avoided during pregnancy through fear } \\
\text { of single child infertility, since banana tree } \\
\text { fruits only once }\end{array}$ & 98 & 0 **** \\
\hline Regular consumption of iron folic acid tablets & 100 & 100 \\
\hline \multicolumn{3}{|l|}{ Cooking practices } \\
\hline $\begin{array}{l}\text { Do not discard excess water (ganji) after } \\
\text { cooking rice }\end{array}$ & 10 & $100 * * *$ \\
\hline Wash vegetables before cutting & 62 & $92 * * *$ \\
\hline \multicolumn{3}{|l|}{ Infant and child feeding practices } \\
\hline Initiate breast feeding within 1 hour after birth & 62 & $92 *$ \\
\hline $\begin{array}{l}\text { Initiate complementary feeding at } \\
7 \text { month of age }\end{array}$ & 68 & $100 * * *$ \\
\hline \multicolumn{3}{|l|}{ Items in complementary food-mothers' knowledge } \\
\hline Rice & 100 & 100 \\
\hline Dal (lentil gruel) & 68 & 78 \\
\hline $\begin{array}{l}\text { Roti (salty pancakes made from cereals or } \\
\text { millets) }\end{array}$ & 6 & $26 * *$ \\
\hline Milk and milk products & 88 & 82 \\
\hline GLV & 22 & $90^{* * * *}$ \\
\hline Vegetables & 28 & $50 * *$ \\
\hline Egg & 36 & $100 * * *$ \\
\hline Yellow of egg fed (normally discarded) & 36 & $100 * * *$ \\
\hline Hand washed with soap and water & 16 & $100 * * *$ \\
\hline \multicolumn{3}{|c|}{ Composition of a balanced diet—mothers' knowledge } \\
\hline Rice & 100 & 100 \\
\hline Roti & 4 & $52 * * *$ \\
\hline Dal & 86 & 94 \\
\hline Vegetables & 42 & $94 * * *$ \\
\hline GLV & 38 & $96^{* * * *}$ \\
\hline Fruits & 0 & 30 *** \\
\hline Milk and milk products & 42 & 46 \\
\hline Eggs & 52 & 52 \\
\hline Meat and fish & 12 & $78 * * *$ \\
\hline
\end{tabular}

No. of respondents in each survey-50. \% of respondents. A twosample proportion $Z$ test was applied to test the significance of the characteristics, since the sample sizes are greater than 30 .

$* p<0.05 ; * * p<0.01 ; * * * p<0.001$.

practices, healthy cooking practices and components of a balanced diet. Improvement in knowledge of-nutrients in foods, functions of different nutrients was weak though majority did mention foods rich in vitamin $\mathrm{A}$ in the end-line survey. Understanding of the cause and management of diseases like diarrhoea (contaminated food and water), malaria (mosquito bite), tuberculosis (through cough) and jaundice (contaminated food and water) showed significant increase. 
Over the years, there has been remarkable increase in women's literacy, antenatal check-ups, institutional deliveries (home deliveries are very rare) and immunisation coverage, in the villages of Medak district where the authors work.

\section{Discussion}

The path from agriculture to nutrition is generally assumed to go via agriculture income. Important as income is; income alone cannot ensure dietary diversification unless the community is educated about the importance a balanced diet, and nutrition, for health and productivity. Emphasis of agriculture is generally on providing calories to quench hunger and at best proteins. This tends to be achieved through cereals and some legumes. Hidden hunger remains hidden from the vision of not only people but also planners and policy makers.

Nutritionally sensitive and environmentally sustainable agriculture is a more holistic approach, in a country like India where agriculture is the main occupation of more than $60 \%$ of the households. Generally farmers are reluctant to deviate from traditional cropping pattern. Yet the studies of the authors and others discussed in this paper show that even small and marginal farmers can be persuaded to diversify into raising homestead gardens of micronutrientdense vegetables and fruits by combining social engineering with technological engineering. Some incentive like giving free planting martial helps. Since most poor rural women work in fields or go for labour work, they were given money for travel and lunch was served, when they came for the centralised meetings to compensate for the lost wage for the day.

As mentioned earlier, homestead gardens may be able to supply vegetables to meet the household requirement, but that alone will not be sufficient to meet the requirement of micronutrients. Inclusion of pulses, millets and animal husbandry along with horticulture should be attempted. The authors did advise about growing pulses and millets, and gave seeds of finger millet and iron fortified pearl millet to interested households. Small but significant improvement in consumption of millets was seen (Table 2). Pulse consumption did not show any increase. Introduction of poultry did help in increasing egg consumption. In the long duration projects (3 years), many families set up vermicompost beds. Incentive by way of earth worms was given. Only few families used botanical pesticides.

The remarkable improvement in the mothers' knowledge of food, nutrition, infant and child feeding practices, sanitation and common communicable diseases, with education, is very gratifying since an informed mother is an empowered mother, and can make a lot of difference to the family's diet, nutrition and health. Involving the local health functionaries also helps sustainability. All community-based technological interventions should have robust educational component so that the community understands the importance of the technological intervention.

Nutrition gardens have recently caught the imagination and attention of many state governments and NGOs in India. Suri has summarised some of these unpublished initiatives [31]. This movement needs to gain momentum with a robust information, education and training strategy. The current Swatch Bharat clean India programme in India will hopefully complement this effort in reducing malnutrition.

Homestead production of diverse foods to ensure dietary diversity assumes particular significance under the present pandemic of coronavirus, when the mobility of humans and material has become highly restricted. Adverse impact on nutrition of not only the traditionally poor people but also low middle income groups slipping into poverty and malnutrition is feared. Micronutrients have been shown to stimulate immunity and thus protect against viral diseases $[32,33]$. To mitigate deficiency, supplementation with immunity stimulating micronutrients has been recommended since a balanced diet cannot be assured [32].

Acknowledgements The technical support for the studies conducted by the Dangoria Charitable Trust was provided by N. Venkatesh (agriculture and horticulture), P. Pentiah (poultry) and K. V. Lakshmi (cooking demonstrations). Help from the following scientists as resource persons for conducting the training programmes is gratefully acknowledged: A. Lakshmiah, G. M. Subba Rao and Raja Siswan Mamidi, National Institute of Nutrition, Hyderabad. M. Srinivs, (horticulture), M. Uday Kumar, (agricultural engineering) and K. Murli Mohan (soil science), Ekalavya Krishi Vigyan Kendra, Tuniki, Medak district. K. Kotaiah Indbro Research and Breeding Farms Ltd., Hyderabad. Dangoria Charitable Trust for all the facilities provided. Last but not the least the ICDS authorities, functionaries and the community for their cooperation.

\section{Compliance with ethical standards}

Conflict of interest The authors declare that they have no conflict of interest. Also, the little bit of unpublished recent research reported is original.

Publisher's note Springer Nature remains neutral with regard to jurisdictional claims in published maps and institutional affiliations.

\section{References}

1. Calkins K, Devaskar SU. Fetal origins of adult disease. Curr Probl Pediatr Adolesc Health Care. 2011;41:158-76.

2. Sharma J, Kishore A, Roy D, Joshi KA. Comparison of the Indian diet with the EAT-Lancet reference diet. BMC Public Health. 2020;20:812.

3. National Nutrition Monitoring Bureau (NNMB). Diet and nutrition status of rural population, prevalence of hypertension \& 
diabetes among adults and infant \& young child feeding practices. Technical report No.26.2012. Hyderabad: National Institute of Nutrition, Indian Council of Medical Research.

4. Sivaprasad M, Shalini T, Yadagiri P, Seshacharyulu M, Madhavi G, Naveen Kumar B, et al. Prevalence of vitamin deficiencies in an apparently healthy urban adult population: assessed by subclinical status and dietary intakes. Nutrition. 2019;63-64:106-13.

5. Nair KM, Bamji MS. Chapter 8: The challenge of hidden hungermicronutrient deficiencies. In: Peter KV, editor. Zero hunger India: policies and perspectives. New Delhi: Brillion Publishing; 2018. p. 205-231.

6. WHO/FAO, Allen L, de Benoist B, Dary O, Hurrell R, editors. Guidelines on food fortification with micronutrients. Geneva, Switzerland: World Health Organisation/Food and Agriculture Organisation of UN; 2006.

7. Bouis HE, Salzman A. Improving nutrition through biofortification: a review of evidence from Harvest Plus 2003 through 2016. Glob Food Sec. 2017;12:49-58.

8. Ramachandran P. National programmes to improve food security and nutritional status. In: Bamji MS, Krishnaswamy K, Brahmam GNV, editors. Text book of human nutrition. 4th ed. New Delhi, India: Oxford \& IBH Publishing Co.; 2016. p. 527-49.

9. FAO technical consultation on food fortification: technology and quality control. Micronutrient fortification of food: technology and quality control, Rome, Italy, 20-23, 1995.

10. Rao BSN, Nair KM. Food fortification-principles and application. In: Bamji MS, Krishnaswamy K, Brahmam GNV, editors. Text book of human nutrition. 4th ed. New Delhi, India: Oxford \& IBH Publishing Co.; 2016. p. 511-526.

11. Thomson B, Amoroso L, editors. Combating micronutrient deficiencies: food based approaches. Rome: FAO and CAB International; 2011.

12. Shetty P. Nutrition sensitive agriculture to achieve better nutritional outcomes. Eur J Clin Nutr. 2018;72:1296-9.

13. Bamji MS, Nair MK. Food based approach to combat micronutrient deficiencies. Proc Indian Natl Sci Acad. 2016;82: 1529-40.

14. Joshi PK, Parappurathuand S, Kumar P. Dynamics of food consumption and nutrient security in, India. Proc Indian Natl Sci Acad. 2016;82:1587-99.

15. Vijayaraghavan K, Nayak UM, Bamji MS, Ramana GNV, Reddy V. Home gardening for combating vitamin A deficiency in rural India. Food Nutr Bull. 2017;18:337-43.

16. Chakravarty I. Food-based strategies to control vitamin A deficiency. Food Nutr Bull. 2000;21:135-43.

17. Bushamuka VN, de Pee S, Talukdar A, Kiess L, Panagides D, Taher A, et al. Impact of homestead gardening program on household food security and empowerment of women in Bangladesh. Food Nutr Bull. 2005;26:17-25.

18. Iannoti L, Cunningham K, Ruel M. Improving diet quality and micronutrient nutrition. Homestead food production in Bangladesh. IFPRI discussion paper 00928, prepared for the project on Millions fed: proven successes in agriculture development. IFPRI;
2009. p. 1-44. https://www.ifpri.org/publication/improving-dietquality-and-micronutrient-nutrition.

19. Rahman FMM, Mortuza MGG, Rahman MT, Rokoinuzzaman M. Food security through homestead vegetable production in the smallholder agricultural improvement project (SAIP) area. J Bangladesh Agric Univ. 2008;6:261-69.

20. Talkukdar A, Haselow NJ, Osel AK, Villate E, Rearioi D, Kroeun $\mathrm{H}$, et al. Homestead food production model contributes to improved household food security and nutrition status of young children and women in poor populations. Field Actions Sci Rep. 2010. revues.org/index404.html.

21. Das PK, Bhavani RV, Swaminathan MS. A farming system model to leverage agriculture for nutritional outcomes. Agric Res. 2014;3:193-203.

22. Nagarajan S, Bhavani RV, Swaminathan MS. Operationalising the concept of farming system for nutrition, through the promotion of nutrition-sensitive agriculture. Curr Sci. 2014;107:959-63.

23. Bhaskar AVV, Nithya DJ, Raju S, Bhavani RV. Establishing agriculture-nutrition programme to diversify household food and diets in rural India. Food Sec. 2017. https://doi.org/10.1007/ s12571-017-0721-z.

24. Pradhan A, Sathanandan R, Panda AK, Wagh R. Improving household diet diversity through promotion of nutrition gardens in India. Am J Food Sci Nutr. 2018;5:43-51.

25. Garcia MT, Rebeiro SM, Camargo AC, et al. The impact of urban gardens on adequate and healthy food: a systematic review. Public Health Nutr. 2018;21:416-25.

26. Bamji MS, Murty PVVS, Rao VM, Satyanarayana G. Diversification from agriculture to nutritionally and environmentally promotive horticulture in a dry-land area. Sight Life. 2011;25:38-42.

27. Murty PVVS, Rao Vishnuvaradhan, Bamji MS. Impact of enriching the diet of women and children through health and nutrition education, introduction of homestead gardens and backyard poultry in rural India. Agric Res. 2016;5:210-7.

28. Murty PVVS, Bamji MS, Vishnu vardhan Rao M, Prasad VLK. Promotion of backyard poultry for augmenting egg consumption in rural households. Indian. Indian $\mathrm{J}$ Nutr Diet. 2013;50:150-5.

29. Pica-Ciamarra U, Otte J. Poultry food security and poverty in India: looking beyond the farm gate. World Poultry Sci J. 2010;66:309-20.

30. Government of India. Basic animal husbandry statistics. New Delhi: Ministry of agriculture, Government of India; 2006.

31. Suri S. Nutrition Gardens: a sustainable model for food security and diversity. ORF issue brief no. 369. Observer Research Foundation; 2020.

32. Calder PC, Carr AC, Gombart AF, Eggerso M. Optimal nutritional status for a well-functioning immune system is an important factor to fight against viral infections. Nutrients. 2020;12:1181. 10. 3390/nul12041181.

33. Gavin-Smith B. The role of nutrition in the immune system: should we pay more attention? New Delhi, India: Sight and life; 2020. 